\title{
Von Neumann, o cientista e a figura humana
}

\author{
IMRE SIMON
}

J OHN VON NEUMANN foi um dos gigantes da ciência deste século; que certamente é o século mais rico, até agora, em avanços científicos. Com certeza, também, vários desses avanços foram influenciados pela marca pessoal de John von Neumann. Além de ter contribuições muito importantes em matemática pura, que por si só justificariam um evento como este, ele deve ser considerado como o fundador da moderna Matemática aplicada devido às suas contribuições seminais à realização dos primeiros computadores digitais, à teoria econômica e à moderna previsão numérica do tempo, para citar apenas algumas das áreas que ajudou a fundar, sempre com contribuições profundas que integram as características fundamentais dessas áreas até hoje, quase 40 anos após o seu falecimento.

John von Neumann faleceu prematuramente, em 1957, vítima de câncer, aos 53 anos de idade. Suas Obras completas foram publicadas em seis volumes, em 1963, editadas por A. H. Taub, perfazendo mais de 3.500 páginas. Vale a pena observar que as obras completas mencionadas não incluem seis livros, nem várias das suas obras não-publicadas, algumas das quais vêm merecendo, com o passar do tempo, estudos cada vez mais meticulosos em função da sua.crescente importância histórica. Quatro exemplos são dados por Knuth (1970), von Neumann (1993), von Neumann (1989) e Nagy-Horváth-Nagy (1989).

Os principais marcos da carreira de John von Neumann estão enumerados na cronologia abaixo, reproduzida de Bochner (1958).

1903 Nasce, Budapest, Hungria, 28 de dezembro.

1930-33 Professor visitante, Universidade de Princeton.

1933-57 Professor de Matemática, Instituto de Estudo Avançado, Princeton, N.J.

1937 Conferencista Gibbs, Conferencista acadêmico, Prêmio Bôcher, todos na Sociedade Americana de Matemática.

1940-57 Comitê Consultivo Científico, Laboratórios de Pesquisa Balística, Campo de Provas de Aberdeen, Maryland. 
1941-54 Departamento de Material Bélico da Marinha, Washington, D.C. 1943-55 Laboratório Científico de Los Álamos (AEC), Los Álamos, N.M. 1945-57 Diretor do Projeto do Computador Eletrônico, Instituto de Estudo Avançado, Princeton, N.J.

1947 D.Sc. (hon.), Universidade de Princeton; Medalha por Mérito (prêmio presidencial); Prêmio por Serviços Civis Notáveis, Marinha dos EUA.

1947-55 Laboratório Naval de Material Bélico, Silver Spring, Maryland.

1949-53 Conselho de Pesquisa e Desenvolvimento, Washington, D.C.

1949-54 Laboratório Nacional de Oak Ridge, Tennesee.

1950 D.Sc. (hon.), Universidade de Pennsylvania e Universidade de Harvard.

1950-55 Projeto de Armamentos Especiais das Forças Armadas, Washington, D.C.; Grupo de Avaliação de Sistemas de Armamentos, Washington, D.C.

1950-57 Membro da Junta de Conselheiros, Universidade de Los Andes, Colômbia, América do Sul.

1951-53 Presidente, Sociedade Americana de Matemática.

1951-57 Conselho Científico, Força Aérea dos EUA, Washington, D.C.

1952 D.Sc. (hon.), Universidade de Istambul, Instituto Case de Tecnologia e Universidade de Maryland.

1952-54 Membro, Comitê Consultivo Geral, Comissão de Energia Atômica dos EUA, Washington, D.C. (nomeação presidencial).

1953 D.Sc. (hon.), Instituto de Politécnica, Munique; Conferencista Vanuxem, Universidade de Princeton.

1953-57 Painel Técnico-Consultivo sobre Energia Atômica, Washington, D.C.

1955-57 Delegado de Energia Atômica dos EUA (nomeação presidencial).

1956 Medalha da Liberdade (prêmio presidencial); Prêmio Comemorativo Albert Einstein; Prêmio Enrico Fermi.

1957 Morre, Washington, D.C., 8 de fevereiro.

Associaçẫo a Academias:

Academia Nacional de Ciências Exatas, Lima, Peru.

Academia Nacional de Lincei, Roma, Itália.

Academia Nacional de Artes e Ciências.

Sociedade Americana de Filosofia.

Instituto Lombardo de Ciências e Letras, Milão, Itália.

Academia Nacional de Ciềncias.

Real Academia de Ciências e Letras da' Holanda, Amsterdam, Holanda. 
Focalizaria agora uma questão intrigante: aonde estão as contribuiçôes principais de John von Neumann à ciência, na área da matemática pura ou nas diversas áreas da chamada matemática aplicada? Antes de prosseguir, gostaria de esclarecer, todas as vezes que esta questão the foi colocada ele nunca titubeou sequer para responder que era um matemático puro. De fato, como já foi dito, ele possui inúmeras contribuições de primeira grandeza, de acentuada beleza e de aplicabilidades crescentes à matemática pura. Basta lembrar que seus trabalhos sobre álgebras de operadores abriram o caminho para as pesquisas recentes de dois brilhantes matemáticos, Alain Connes e Vaughan Jones, agraciados com a medalha Fields, condecoração máxima na área, em 1982 e em 1990, respectivamente.

Mas, na minha opinião, correndo mesmo o incômodo risco de contrariar o próprio John von Neumann, é na matemática aplicada que estão as suas maiores realizaçóes, pelo menos no sentido do seu impacto em nossa vida cotidiana, sua durabilidade e sua extrema originalidade. Estou me referindo principalmente às suas contribuiçôes que foram revistas nas palestras sobre a Economia, a Computação, a Meteorologia e a Física. Preciso acrescentar ademais que deveriam constar também nesta lista muitas outras contribuições de John von Neumann não abordadas no nosso evento, como, por exemplo, suas contribuições à análise numérica ou à teoria dos autômatos as quais são substanciais. Consta ainda que nos anos precedentes à sua morte ele depositava forte esperança na maturação de suas idéias sobre certas teorias que pudessem modelar o funcionamento do cérebro e de sistemas complexos com muitos componentes. Acredito ter havido muito pouco progresso na área nestes 40 anos e pode perfeitamente ser o caso de que a morte prematura de John von Neumann privou o mundo de descobertas espetaculares nesse campo do conhecimento.

Existe ainda outra visão que aponta para a matemática aplicada como a área das maiores realizações de John von Neumann. De fato, ele certamente foi o primeiro matemático que conviveu intimamente e com grande intensidade com os computadores, ou seja, o primeiro matemático que incorporou em sua ciência essa máquina que está mudando, e acreditamos, mudará ainda mais, os contornos de todas as ciências. Os da Matemática inclusive. Ou, talvez, até mesmo principalmente; só o tempo poderá responder a tal questão. O fato é que John von Neumann, além de ser o principal idealizador, no curso de um intenso processo que se desenrolou entre agosto de 1944 e junho de 1945, da estrutura lógica da máquina, basicamente como ela existe até os nossos dias, lançou-se de imediato a explorar as possibilidades dos seus usos. Infelizmente, ele 
deve ter sido bastante debilitado nessas atividades pela necessidade que sentiu de ter de aplicar parte da sua capacidade criadora na própria construção de um dos primeiros computadores, o IAS-52, tarefa que levou seis preciosos anos para ser completada. Mesmo assim, uma análise dos seus trabalhos, desde a formulação da estrutura lógica dos computadores até o fim da sua vida, revela um cientista que antecipou, experimentou, explorou e ajudou a forjar, com grande intensidade, um número impressionante de aplicações desses equipamentos, tanto na própria área emergente da computação quanto na modelagem de várias outras áreas, sempre com o pleno uso do impressionante arsenal matemático que manuseava com habilidade e facilidade inigualáveis. Mas não é esta a essência da moderna matemática aplicada? Assim, dependendo ainda dos rumos que a Matemática e a Computação tomarão nas próximas décadas, o futuro poderá delinear, com maior nitidez ainda do que já delineou, um John von Neumann que tanto pela sua postura quanto por suas realizações foi o precursor dos rumos que a Matemática tomaria.

Gostaria de voltar a frisar a amplitude e a interdisciplinaridade incomuns da obra de John von Neumann, parâmetros muito difíceis de serem conseguidos. De fato, é fácil verificar que aproximadamente $25 \%$ dos institutos da Universidade de São Paulo, representando aproximadamente $25 \%$ do conhecimento humano, possuem docentes cujo trabalho de pesquisa sofreu e ainda sofre as influências diretas e marcantes das suas idéias. Gente que está familiarizada com os detalhes do seu trabalho em alguma área e que sente profundo respeito por e enorme gratidão a John von Neumann em função das suas contribuições à área de cada um. Gente que se sensibiliza com a sua obra científica. Uma cifra impressionante e muito difícil, senão impossível, de igualar! Evidentemente, neste cálculo não foram computados os simples usuários dos computadores ou da previsão de tempo, só para citar duas áreas que provavelmente seriam muito diferentes não tivessem contado com o seu espírito criador. Aí, a contagem simplesmente iria para $100 \%$ !

\section{John von Neumann, a figura humana}

John von Neumann era uma figura humana marcante sobre a qual correm muitas lendas e algumas controvérsias também. Algumas das palestras proferidas abordaram tais aspectos, más o leitor interessado poderá encontrar muito mais material na literatura mencionada nas referências.

Gostaria de tecer agora alguns comentários sobre essas controvérsias. 
Além das suas atividades científicas, John von Neumann foi também um homem poderoso, com idéias muito originais e freqüentemente pouco convencionais. Além disso, foi uma dessas raras personalidades com enorme talento para realizar o pouco convencional. Na verdade, tais características contribuíram para que ele ajudasse a mudar o rumo do nosso mundo em vários aspectos. Características de um cientista verdadeiramente excepcional. Para exemplificar, basta lembrar que ele montou um substancial laboratório de engenharia no Institute for Advanced Study, em Princeton, para construir um computador, um instrumento que não estava e não está na linha da vocação principal daquele famoso instituto!

Acredito que essas características valeram a John von Neumann alguns amigos não muito entusiasmados com as novidades por ele introduzidas. Adicione-se a isto o poder substancial advindo, durante e depois da Segunda Guerra Mundial, de suas funçôes de consultor de inúmeras organizações militares e de membro da Comissão de Energia Atômica dos EUA, por designação do presidente Eisenhower, e assim resultará um personagem controvertido, discutido e divisivo que também é a figura de John von Neumann. Acredito mesmo que essas suas características tendem a retardar a formação de um consenso sobre o cientista John von Neumann que possuía inspiração extraordinária, idéias e técnicas científicas poderosíssimas, além da vontade inquebrantável de aplicar o seu raciocínio matemático a um conjunto variado de ramos do conhecimento humano. Isto, por sua vez, talvez tenha dificultado até que os seus méritos fossem amplamente conhecidos e a sua figura apropriadamente reverenciada.

Acredito, porém, que esta é uma situação passageira, pois o contínuo crescimento da importância e da relevância da sua obra vai se encarregar de, simultaneamente, realçar os aspectos positivos e atenuar, de forma natural, os aspectos negativos dessas controvérsias.

É por tais questões, também, que considero importante a realização de encontros como este, para podermos melhor apreciar, avaliar, discutir e disseminar a obra desse grande cientista, refletindo, cada um de nós, sobre o alcance das suas contribuições científicas.

\section{A bibliografia}

Certamente, John von Neumann já é um dos cientistas sobre quem mais se escreve. Não me refiro aqui a conseqüências estritamente científicas e técnicas das suas idéias; estas devem ser conferidas pelos especialistas em cada uma das suas áreas de atuação. A este respeito, menciono 
apenas que em recente busca eletrônica nos bancos de dados da American Mathematical Society, contidos no sistema MáthSciNet, foi revelada a existência de mais de 1.000 artigos científicos, apenas nas áreas das Ciências Matemáticas, cujo título contém o seu nome! Refiro-me a livros e artigos que tratam principalmente da figura do cientista e da figura humana de John von Neumann.

Para facilitar a localização do referido material foi incluída neste trabalho uma bibliografia parcial dos livros e dos principais artigos escritos no espírito apontado. Gostaria de frisar que, apesar de ser bastante incompleta, foi incluída aqui principalmente no sentido de facilitar ao leitor interessado a localização da literatura sobre John von Neumann.

Referências bibliográficas

AGERWALA, T. \& ARVIND, Eds. Computer (special number), v. 15(2). IEEE, 1982.

ASHENHURST, R. L. \& GRAHAM, S., Eds. ACM Turing Award Lectures, The First Twenty Years. ACM Press Anthology Series. Addison-Wesley Publishing Company, Reading, MA, 1987.

ASPRAY, W. The mathematical reception of the modern computer: John von neumann and the institute for advanced study computer. In Studies in the History of Mathematics, E. R. Phillips, Ed., v. 26. MAA, Washington DC, 1987, pp. 166-194.

John von Neumann and the origins of modern computing. The MIT Press Series in the History of Computing. MIT Press, Cambridge, MA, 1990.

From Mathematical Constructivity to Computer Science: Alan,Turing, John von Neumann, and the origins of computer science in matehmatical logic. PhD theșis, Univ. of Wisconsin, Madison, 1980.

ASPRAY, W. \& BURKS, A. W., Eds. Papers of John von Neumann on Computing and Computer Theory, v. 12 of Charles Babbage Institute Reprint Series. The MIT Press, 1987.

BOCHNER, S. John von Neumann. In Biographical Memoirs, Vol. 32. National Academy of Sciences, 1958, p. 447.

BRINK, J. R. \& HADEN, C. R., Eds. The Computer and the Brain: An In- 
ternational Symposium in Commemoration of John von Neumann (19031957) (1989), v. 11(3) of Annals of the History of Computing (special number).

BRUCKMANN, G. \& WEBER, W., Eds. Contributions to the von Neumann Growth Model (New York, 1971), Springer Verlag.

BURKS, A. R. \& BURKS, A. W. The First Electronic Computer: The Atanasoff Story. University of Michigan Press, Ann Arbor, 1988. Review in Annals of the History of Computing, 10:3 (1988), 222-223.

CAMPBELL, D. M. \& HIGGINS, J. C., Eds. Mathematics: people, problems, results, v. 1. Wadsworth International, 1984.

DANILOV, Y. A. John von Neumann (in Russian). Current Life, Science and Technology: Series Mathematics and Cybernetics. Znanie, Moscow, 1990. MR 92e:01056.

DIEUDONNÉ, J. von Neumann, Johann. In Dictionary of Scientific Biography, C. G. Gillespie, Ed., v. XIV. Charles Scribner, NY, 1981, pp. 88-92.

DORE, M.; CHAKRAVARTY \& GOODWIN, Eds. John von Neumann and Modern Economics. Clarendon Press, 1989.

FRIEDRICHS, K. O. Von Neumann's Hilbert space theory and partial differential equations. SIAM Rev. 22, 4 1980, p. 486-493. MR 82c:01034.

GLIMM, J.; IMPAGLAZZO, J. \& SINGER, I., Eds. The Legacy of John von Neumann (1990), v. 50 of Proceedings of Symposia in Pure Mathematics, American Mathematical Society.

GODFREY, M. D. \& HENDRY, D. F. The Computer as von Neumann Planned It. Annals of the History of Computing 15, 1 Jan. 1993, p. 11-21.

GOLDSTINE, H. H. The Computer from Pascal to von Neumann. Princeton University Press, 1972.

GOLDSTINE, H. H. \& WIGNER, E. P. Scientific work of John von Neumann. Science 125 1957, p. 683-684.

GRUENBERGER, F. J. The History of JohnNIAC. Annals of the History of Computing 1, 1 July 1979, p. 49-64.

HALMOS, P. R. The Legend of John von Neumann. American Mathematical Monthly 80, 4 Apr. 1973, p. 382-394. 
HEIMS, S. J. John von Neumann and Norbert Wiener, from Mathematics to the Technologies of Life and Death. MIT Press, 1980. see also the reviews of Stone (1983) and Rider (1981).

KNUTH, D. E. Von Neumann's First Computer Program. Computing Surveys 2, 4 Dec. 1970 , p. 247-260.

LARSON, E. R. Findings of Fact, Conclusions of Law and Order for Judgement. File No 4-67 Civ. 138, Honeywell Inc. vs. Sperry Rand Corporation and Mlinois Scientific Developments, Inc. U.S. District Court, District of Minnesota, Fourth Division, 19 October 1973.

LEE, J. A. N. John Louis von Neumann. Available in the WWW under the adress http://ei.cs.vt.edu:80/ history/VonNeumann.html, 1994.

. Computer Pioneers. IEEE Computer Society Press, 1995.

LEGENDI, T. \& SZENTIVÁNYI, T., Eds. Life and work of John von Neumann (in German). Bibliographisches Institut, Mannheim, 1983. Translated from the Hungarian by Rozsa Nienhaus. MR 85e:01054.

MACRAE, N. John von Neumann. Pantheon Books, New York, 1992. Review by S. Mahoney in Annals of the History of Computing, 16:2 (1994), 75-76. See also MR 95g:01023.

MARX, G. The Voice of the Martians. Roland Eotvos Physical Society, H1371 Budapest, P.O.Box 433, 1994. Copies can be ordered at Fax ++36 $1-2018682$.

METROPOLIS, N.; HOWLETT, J. \& ROTA, G.-C., Eds. A History of Computing in the Twentieth Century. Academic Press, New York, 1980.

NAGY, D.; HORVÁTH, P. \& NAGY, F. The John von Neumann-Ortvay Connection. Annals of the History of Computing 11, 3 1989, p. 183-188.

OXTOLEY, J. C.; PETTIS, B. J. \& PRICE, G. B., Eds. John von Neumann 1903-1957, v. 64 of BAMS. AMS, 1958.

POUNDSTONE, W. Prisoner's Dilemma/John von Neumann, Game Theory and the Puzzle of the Bomb. Anchor Books, 1993.

RANDELL, B. Bibliography. In The Origins of Digital Computers, Third Edition, B. Randell, Ed. Springer-Verlag, 1982, pp. 431-544.

Verlag, 1982. 
RANDELL, B. The Origins of Computer Programming. Annals of the History of Computing 16, 4 Oct. 1994, p. 6-14.

RIDER, R. E. Two mathematicians. Science 212, 4502 June 26 1981, p. 1496. A Review of John von Neumann and Norbert Wiener, from Mathematics to the Technologies of Life and Death, by Steve J. Heims.

RITCHIE, D. The Computer Pioneers. Simon \& Shuster, Inc., New York, 1986.

ROSEN, S. Electronic Computers: a Historical Survey. Computing Surveys 1, 1 Mar. 1969, p. 7-36.

SCHNELLE, H. Turing naturalized: von Neumann's unfinished project. In The universal Turing machine: a half-century survey. Oxford Univ. Press, New York, 1988, pp: 539-559.

SLATER, R. Portraits in Silicon. The MIT Press, Cambridge, MA, 1987.

STERN, N. John von Neumann's Influence on Electronic Digital Computing, 1944-1946. Annals of the History of Computing 2, 4 Oct. 1980, p. 349-362.

From ENIAC to UNIVAC: An Appraisal of the Eckert-Mauchly Computers. Digital Press, Bedford, MA, 1981.

STONE, M.H. A review of John von Neumann and Norbert Wiener, from Mathematics to the Technologies of Life and Death, by Steve J. Heims. Bulletin of the American Mathematical Society 8, 2 Mar. 1983, p. 395-399.

TAUB, A. H., Ed. John von Neumann: Collected Works, v. 6 volumes. Oxford University Press, 1963.

TODD, J. John von Neumann and the national accounting machine. SIAM Rev. 161974, p. 526-530.

TROPP, H. S. John von Neumann. In Encyclopedia of Computer Science and Engineering, A. Ralston and J. Edwin D. Reilly, Eds. Van Nostrand Reinhold Co., New York, 1983, pp. 1564-1565.

ULAM, S. John von Neumann, 1903-1957. Bulletin of the American Mathematical Society (volume especial: John von Neumann 1903-1957) 64, 3,2 1958, p. $1-49$.

VON NEUMANN, J. First Draft of a Report on the EDVAC. Unpublished manuscript. An edited version appeared as [51]; the first five sections were reproduced in [35], pages 383-392, 1945. 
VON NEUMANN, J. The Principles of Large-Scale Computing Machines. Annals of the History of Computing 10, 4 Oct. 1989, p. 243-256. With an introduction by Michael R. Williams and a foreword by Nancy Stern.

. First Draft of a Report on the EDVAC. Annals of the History of Computing 15, 4 Oct. 1993, p. 27-75. Referência de von Neumann (1945) editada por Michael D. Godfrey.

VONNEUMAN, N. A. John von Neumann As Seen By His Brother, Rev. ed. Nicholas Vonneuman, Meadowbrook, PA, 1991. MR 89i:01108, by Dieudonné.

WEINTRAUB, E. R., Ed. Toward a history of game theory. Duke Univ. Press, Durham, NC, 1992.

WILKES, M. V. Memoirs of a Computer Pioneer. The MIT Press, Cambridge, MA, 1985.

A Tribute to Presper Eckert. Communications of the ACM 38, 9 Sept. 1995, p. 20-22.

WILLIAMS, M. R. The Origins, Uses, and Fate of the EDVAC. Annals of the History of Computing 15, 1 Jan. 1993, p. 22-38.

YEE, O. P. On the life and work of John von Neumann. Menemui Mat. 4,3 1982, p. 114-127. MR 84e:01087.

Imre Simon é professor do Departamento de Ciência da Computação do Instituto de Matemática e Estatística da USP. Este trabalho do autor contou com o apoio da Fapesp, do CNPq e do programa USP-COFECUB.

Palestra feita pelo autor no encontro A obra e o legado de John von Neumann, organizado pelo Instituto de Estudos Avançados da USP e pela Academia Brasileira de Ciências no Instituto de Matemática e Estatística da USP em 14 de novembro de 1995. 